\title{
Protagonismo Juvenil, Pedagogia Social e o Pensamento Pedagógico Freireano: alguns desafios e perspectivas para a formação de educadores e educadoras sociais em projetos socioeducativos
}

\author{
SILVA Alexandre Magno Tavares da ${ }^{1}$
}

\begin{abstract}
Resumo
Este artigo discute algumas experiências e reflexões a partir do trabalho dos educadores e educadoras sociais que estão ativos em projetos sócio-educativos para cuidar de crianças, adolescentes e jovens em condições de pobreza no Nordeste brasileiro. Com base nas considerações de Paulo Freire, vamos nos concentrar no Protagonismo Juvenil como categoria e prática social e educacional para discutir a posição deste conceito no processo de aprendizagem e de trabalho dos educadores e educadoras sociais que atuam em áreas não-escolares. Esta discussão aponta para a necessidade de concentrar uma série de experiências sociais e educativas e de abordar seu desdobramento nos países do Terceiro Mundo e seu impacto social, que - embora ricas em significado e potencial- correm o risco de permanecer despercebidas por parte da atenção acadêmica que não se dá conta dessas áreas como espaços de conhecimento e desenvolvimento de competências. Se o protagonismo juvenil vem alterando os fundamentos teóricos e metodológicos da formação dos educadores sociais, e do trabalho social, certamente afetará e influenciará na ação pedagógica (teórico e metodologica) dos educadores e educadoras sociais. Isto deverá permitir uma experiência intercultural que pode vir a contribuir para criar uma sociedade justa e solidária.
\end{abstract}

Protagonismo Juvenil. Pedagogia Social. Meninos de Ruas. Paulo Freire

\begin{abstract}
o
Este artículo discute algunas experiencias y reflexiones a partir del trabajo de los educadores y educadoras sociales que trabajan en proyectos socio-educativos para cuidar de niños, adolescentes y jóvenes en condiciones de pobreza en el Nordeste brasilero. Con base en las consideraciones de Paulo Freire, nos concentraremos en el Protagonismo Juvenil como categoría y práctica social y educacional para discutir la posición de este concepto en el proceso de aprendizaje y de trabajo de los educadores y educadoras sociales que actúan en sectores no-escolares. Esta discusión apunta la necesidad de concentrar una serie de experiencias sociales y educativas y de abordar su despliegue en los países del Tercer Mundo bien como su impacto social, que aunque ricas en significado y potencial - corren el riesgo de permanecer desapercibidas por parte de la atención académica que no se da cuenta de esas áreas como espacios
\end{abstract}

\footnotetext{
1 Doutor em Ciências da Educação (Pedagogia Social) pela Johann Wolfgang Goethe-Universität (Frankfurt). Educador Social. Atuou como docente na FAFICA e na UFPE/CAA. Atualmente, é professor adjunto da Universidade Federal da Paraíba.
} 
de conocimiento y desarrollo de competencias. Si el protagonismo juvenil viene cambiando los fundamentos teóricos y metodológicos de la formación de los educadores sociales, y del trabajo social, sin duda puede afectar e influenciar en la acción pedagógica (teórica y metodológica) de los educadores y educadoras sociales. Esto debe permitir una experiencia intercultural que puede venir a contribuir para crear una sociedad justa y solidaria.

\section{Protagonismo Juvenil. Pedagogía Social. Niños de la Calle}

\section{Introdução}

Nos últimos anos, temos percebido um aumento significativo no envolvimento de adolescentes, jovens e adultos dos espaços populares que, inquietos diante das situações de pobreza, marginalização e exclusão social, bem como com uma curiosidade pelo mundo que os rodeia, vão tecendo possibilidades para melhor compreender e intervir neste quadro. Diversos autores têm chamado a atenção para este quadro.

Esse exercício, que envolve um dar-se conta da realidade, é mediado por uma série de objetos e por um "mundão" de coisas que estão por dentro e por trás desses objetos. Vale resgatar, na literatura brasileira uma passagem do texto de Ubaldo Ribeiro no Livro Viva o povo Brasileiro.

Tinha gente que pescava o peixe, gente que plantava a verdura, gente que fiava o pano, gente que trabalhava a madeira, gente que fazia o pão, gente que tecia a rede, gente de toda espécie, e tudo requeria grande conhecimento e muitas coisas por dentro e por trás desse conhecimento - talvez fosse isto a vida, como ensinava a Vó Leléu, quanta coisa existia na vida! Que beleza era a vida cada objeto um mundão com tantas coisas ligadas a ele e até um pedaço de pano teve alguém para prestar atenção só nele um dia, até tecê-lo e acabá-lo e cortá-lo, alguém que tinha conhecimento tão grande como esses pescadores e navegadores, mas já se viu coisa mais bonita neste mundo do nosso Deus. (RIBEIRO, 1984, p.318)

Esta literatura resgata o espanto de uma personagem, Maria da Fé, que desejava ser professora, mas ao contemplar o cotidiano da sua comunidade de pescadores e pescadoras, e passando a perceber a complexidade que envolvia a atividade, decidiu ser, primeiro, pescadora, para depois construir-se professora. 


\section{O Fazer como Aprender}

Em muitos espaços sociais podem ser identificados o Fazer como Aprender no processo participativo de educadores, educadoras, educandos e educandas. Nesse sentido, gostaríamos de destacar, enquanto espaços sociais, os chamados Projetos Socioeducativos com crianças, adolescentes e jovens em situação de rua e vulnerabilidade social em periferias urbanas. Estes projetos continuam sendo espaços de pesquisas e programas extensionistas de universidades. O escolher da nossa trajetória em antropologia, na UFPE, em 1982, o mestrado em Educação Popular em 1992, o Doutorado em Pedagogia Social em 1996, foram movidos pelo desejo de melhor compreender a experiência social que tecia junto com companheiros e companheiras, desde 1979, na Pastoral de Juventude do Meio Popular na arquidiocese de Olinda e Recife, até o Centro de Educação Popular Comunidade Viva em 2015.

Se por um lado a produção de conhecimentos no espaço acadêmico está carregada de possibilidades teóricas de interpretação e análise da estrutura social, com referenciais psicológicos, filosóficos, econômicos, sociológicos, antropológicos etc., por outro se torna necessário que o espaço acadêmico conheça de que forma está ocorrendo o processo de dar-se conta da realidade social, da produção de saberes nas práticas cotidianas, nas experiências sociais protagonizadas pelos próprios educadores, educadoras, educandos e educandas dos Projetos Socioeducativos.

Pesquisas nesses espaços sociais tornam-se necessárias precisamente para possibilitar um reconhecimento e visualização do papel desses atores sociais, que, atuando em espaços não escolares enquanto sujeitos históricos, produtores de saberes e conhecimentos, vão apontando outras formas de sentir, pensar e agir em torno da pedagogia. Projetos Socioeducativos com crianças, adolescentes e jovens em situação de rua e vulnerabilidade social são repletos de atividades empapadas com fazeres pedagógicos que, atualmente, estão colaborando na própria reconfiguração da educação básica. Esses fazeres pedagógicos partem da necessidade de compreender o lugar que cada objeto ocupa no processo socioeducativo. Em nosso trabalho de doutorado, concluído 
em outubro de 2000 tivemos a oportunidade de discutir alguns desses elementos dos quais, destacamos:

- O trabalho socioeducativo como resultado da luta de mulheres pescadoras por melhores condições de vida de crianças e adolescentes (projeto socioeducativos na cidade de Recife);

- O trabalho socioeducativo como uma proposta de educação profissional alter(n)ativa para jovens da área rural (projeto socioeducativo na cidade de Limoeiro);

- O trabalho socioeducativo como prática de uma educação popular junto a meninos e meninas de rua (projeto na cidade de Caruaru);

- O trabalho socioeducativo como proposta de organização de meninos trabalhadores (projeto socioeducativo na cidade de Salgueiro);

- O trabalho socioeducativo como ensaio de rediscutir o trabalho artesanal frente às novas exigências da organização do trabalho via caridade assistencial (projeto socioeducativo na cidade de Gravatá).

Os cinco aspectos acima, discutidos no trabalho de pesquisa, apontam para a necessidade de estudarmos os processos educativos construídos nesses espaços, levando em conta a ótica de criação dos próprios educadores, educadoras, educandos e educandas. Nesse sentido, uma das experiências significativas foi o trabalho de formação de educadores sociais desenvolvido pelo coletivo, MACA. O coletivo Movimento de Meninos e Meninas de rua foi estruturado em finais dos anos 80 e permaneceu até o ano de 2006, pelos educadores e educadoras sociais que participavam de projetos socioeducativos no Estado de Pernambucoi.

A formação de educadores e educadoras nos projetos socioeducativos, na época, chamados de Projetos Alternativos de Atendimento a Crianças e Adolescentes marginalizados, nasceu da preocupação de coordenadores e educadores sociais, desses projetos, em discutir e apresentar melhores condições de realizar o trabalho socioeducativo com uma visão mais clara e concreta dos seus objetivos, conteúdos, metodologias e que apontasse, sobretudo, para uma transformação da realidade de vida das crianças, adolescentes e jovens em situação de rua e vulnerabilidade pessoal e social.

A reflexão desses objetivos, conteúdos e metodologias e resultados no trabalho educativo na vida dos educadores, educadoras, educandos e educandas dá-se em uma realidade concreta: nas atividades desenvolvidas nas quais esses 
sujeitos históricos estavam, na época, em constante relação. Nesse sentido, entre as atividades pensadas nos encontros formativos, tínhamos:

- Atendimento à saúde

- Alimentação

- Recreação e esporte

- Artes, musicalidade, dança e teatro,

- Alfabetização

- Evangelização

- Escolarização

- Acompanhamento e reforço escolar

- Atendimento as famílias

- Atividades artesanais

- Iniciação a profissionalização

- Grupos de produção e comercialização

- Atividades agrícolas

- Encaminhamento para o mundo do trabalho.

Os fundamentos teórico-metodológicos utilizados diziam respeito ao nosso desejo de realizar uma leitura do mundo nas atividades acima; por isso os três caminhos inspirados no pensamento pedagógico de Paulo Freire eram.

- A PARTIR DA PRÁTICA CONCRETA perguntando e problematizando a prática, supondo a identificação de fatos e situações significativas da realidade imediata;

- TEORIZAR SOBRE A PRÁtICA, ir além das aparências imediatas, desvelar, refletir, discutir, estudar criticamente, buscando conhecer melhor o tema problematizado. Explicar é descobrir as causas e as leis das relações entre fatos. A teoria sintetiza, relaciona os fatos num todo único.

- VOLTAR À PRÁTICA PARA TRANSFORMÁ-LA, com referências teóricas mais elaboradas e agir de modo mais competente, novas perguntas requerem novos processos de teorização, abrindo-nos ao movimento espiralado da contínua busca do conhecimento.

Estávamos nos primeiros passos do que chamamos Sistematizações de Experiências em Educação Popular. Quando tomamos a Educação Popular como Projeto teórico-metodológico a fim de pensar a prática, desejamos nos apoiar em alguns elementos constitutivos dela que nos possibilita concebê-la, segundo Carrilo, 2007, como: 
Uma lectura crítica Del orden social vigente y um cuestionamiento $A L$ papel integrador que há jugado allí la educación formal; 2) Uma intencionalidad política emancipadora frente AL ordem social imperante; 3) Um propósito de contribuir al fortalecimiento de los sectores dominados como sujeito histórico, capaz de protagonizar El cambio social; 4) Uma convicción que desde lá educación ES posible contribuir al logro de esa intencioanlidad, actuando sobre La subjetividad popular; 5) Um afán por generar y emprear metodologías educativas dialógicas, participativas y activas. (CARRILO, 2007, p.14).

As temáticas discutidas eram inspiradas no cotidiano do trabalho socioeducativo. Pelo significado dessas experiências e, sobretudo, pela participação política proporcionada, várias experiências educativas de projetos socioeducativos no Brasil se tornaram referências no que diz respeito à reconfiguração das políticas públicas de atendimento a crianças, adolescentes e jovens, bem como na educação básica. Destacamos a situação atual do Programa de Estímulo à Criatividade na Educação Básica, cujo objetivo é o de criar as bases para uma política pública de fomento a inovação e criatividade na Educação Básica.i

As organizações não escolares que atuam com a infância e a adolescência, por vezes, têm tido mais espaço para a inovação, adotando princípios organizacionais que estimulam a autonomia, flexibilidade, participação, integração com a comunidade e o uso inteligente das novas tecnologias. No entanto, por serem identificadas como instituições de assistência social ou de lazer; não como instituições educativas têm pouca influência sobre as redes de ensino, as escolas e a formulação de políticas públicas na área.iii

Um dos aspectos significativos desta jornada está na reconfiguração do papel exercido pelas crianças, adolescentes e jovens nos projetos socioeducativos. A possibilidade de tomá-los enquanto sujeitos ativos e protagonistas vêm ganhando força ao falarmos sobre processos educativos emancipatórios. Nesse sentido, nosso texto tem o objetivo de apresentar algumas reflexões em torno da pedagogia social no contexto do protagonismo juvenil dentro dos projetos socioeducativos com crianças, adolescentes e jovens em situação de rua e vulnerabilidade social, bem como refletir a contribuição do pensamento pedagógico freireano. Para tanto abordaremos três aspectos que nos ajudam a definir a Pedagogia Social como categoria de estudo: 
- Adolescentes e jovens enquanto protagonistas no espaço social;

- Dando-se conta da rua enquanto espaço de atuação;

- Paulo Freire e os educadores sociais: possibilidades de uma proposta alter(n)ativa no mirar a criança e o adolescente enquanto protagonistas na ação socioeducativa.

\title{
2 Crianças, adolescentes e jovens enquanto protagonistas no espaço social
}

\author{
De sua formosura \\ Deixai-me que diga: \\ É belo como coqueiro que vence a areia marinha. \\ Belo como o avelós contra o Agreste de cinza. \\ Belo como a palmatória na caatinga sem saliva. \\ É tão belo como um sim numa sala negativa. \\ Belo porque é uma porta abrindo-se em mais saídas. \\ Belo porque tem o novo a surpresa e a alegria. \\ Belo como a coisa nova na prateleira até então vazia. \\ Como qualquer coisa nova inaugurando o seu dia, \\ Ou como o caderno novo quando a gente o principia. \\ É belo com o novo todo velho contagia. \\ Belo porque corrompe com sangue novo a anemia. \\ Infecciona a miséria com a vida nova e sadia. \\ Com oásis, o deserto, com ventos, a calmaria. \\ João Cabral de Melo Neto
}

Embora se perceba a importância das crianças, adolescentes e jovens enquanto personagens ativos dentro da estrutura social, estes ainda não foram plenamente reconhecidos nesse papel, sendo excluídos das formas ativas de participação social e política.

el concepto de niño es un concepto culturalmente construido y por ello mismo no es universalizable en su formación ni homogeneizable; no puede por ello ser dogmático pues es por naturaleza evolutivo y sobre-determinado por los procesos socio-culturales y económico-políticos. [...] Tenemos que reconocer que las culturas dominantes nos imponen una ideología del niño que es funcional a los proyectos sociales, económicos y políticos de la dominación. (SCHIBOTTO 1990, p. 363s).

Uma das causas para esta postura decorre da imagem construída sobre a infância e a juventude ao longo da história que, muitas vezes, está enraizada em um olhar sociocêntrico e criminalizante por parte da sociedade. 
Naquele momento, uma versão marginalizadora e preconceituosa das crianças das classes populares agudizavase e tornava-se hegemônica, não só no cenário nacional, mas em todos os países do então chamado Terceiro Mundo, de tal modo que a infância pobre e fracasso na escola pública apareciam como elementos de um inseparável e quase insuperável problema social. (KRAMER; LEITE, 2001, p. 15).

Por outro lado, há também a falta de pesquisas em torno da produção de saberes e competências desses adolescentes e jovens em suas experiências de vida no cotidiano social, no mundo da escola, da comunidade, da família, do trabalho, etc. (cf. SILVA 2001, p.12-13). Entretanto vão se tecendo novas formas de olhar, interpretar e agir e, cujo resultado, está, cada vez mais, fazendo parte das iniciativas de formação dos educadores e educadoras sociais.

A conquista do Estatuto da Criança e do Adolescente, ECA, Lei 8.069 de 13 de julho de 1990, garantiu os direitos das crianças e adolescentes no Brasil e contribuiu, significativamente, nesses vinte e cinco anos para a reconstrução da imagem em torno das crianças, adolescentes e jovens, passando estes a serem vistos não como meros Objetos (passivos) da assistência social e educativa, mas sim como a Sujeitos Sociais (ativos) nas ações socioeducativas.

Apesar do penoso caminho nas conquistas das políticas públicas, temos hoje um conjunto de medidas, marcos legais, planos nacionais que vem colaborando, significativamente, tanto no enfrentamento das situações de marginalização, criminalização e exclusão social, quanto no revisitar alguns paradigmas e conceitos no campo sócio-político-pedagógico, para dar conta desta nova realidade. Entre os marcos legais, temos:

- Plano Nacional de Educação - 2014-2024 (Lei no 13.005, de 25 de Junho de 2014);

- Plano Nacional de Promoção, Proteção e Defesa do Direito de Crianças e Adolescentes à Convivência Familiar e Comunitária / Lei no 12.010, de 03 de agosto de 2009 (Lei do Direito à Convivência Familiar);

- Sistema Nacional de Atendimento Socioeducativo / Lei no 12.594, de 18 de janeiro de 2012 (Lei que institui o Sistema Nacional de Atendimento Socioeducativo e regulamenta a execução das medidas socioeducativas destinadas a adolescente que pratique ato infracional);

- Plano Nacional de Prevenção e Erradicação do Trabalho Infantil e Proteção do Adolescente Trabalhador; 
- Plano Nacional de Enfrentamento da Violência Sexual Infanto-Juvenil;

- Linha de Cuidado para a Atenção Integral à Saúde de Crianças, Adolescentes e suas Famílias em Situação de Violência;

- Plano Integrado de Enfrentamento ao Crack e outras Drogas;

- Programa de Proteção a Crianças e Adolescentes Ameaçados de Morte;

- Tipificação Nacional de Serviços Socioassistenciais;

- Outras leis e planos nacionais relacionados à proteção e promoção dos direitos das crianças e adolescentes.

Esta mudança de olhar sobre as crianças, adolescentes e jovens e os novos marcos legais, encontram nas categorias Protagonismo e na Pedagogia Social elementos favoráveis para o entendimento e a efetivação, não apenas dos direitos fundamentais das crianças, adolescentes e jovens, como resumido no artigo 4ำ do Documento, mas para dar-se conta do protagonismo implícito no cotidiano das lutas populares em suas diversas formas de manifestação. Nesse sentido, o resgate, o entendimento, a tematização em torno da criança, do adolescente e do jovem, enquanto sujeito histórico e social, passa, necessariamente, pelo conhecimento e discussão em torno da presença desse protagonismo também nas lutas populares.

É dever da família, da comunidade, da sociedade em geral, e do Poder Público assegurar, com absoluta prioridade, a efetivação dos direitos referentes à vida, à saúde, à alimentação, à educação, ao esporte, ao lazer, à profissionalização, à cultura, à dignidade, ao respeito, à liberdade e à convivência familiar e comunitária. (BRASIL. ECA, 1990).

As experiênias nas quais estão inseridos estão recheadas de representações; é preciso ouví-las, possibilitar-Ihes a palavra. Deixá-los falar do jeito que vivem e/ou sobrevivem, contar suas histórias, dizer como vêem o mundo, como percebem a realidade, seja na zona rural seja na urbana, apontarem as situações de exploração e como estão construindo estratégias de enfrentamento, nesse sentido, o exercício do ouvir é fundamental por parte do educador e da educadora.

$\mathrm{O}$ ato de ouvir, na perspectiva freireana, refere-se à virtude de saber escutar. Tal virtude é indispensável ao educador que se assumir progressista, exigindo deste o exercício de aprender a ouvir de tal forma que, não se vendo arrogante acima daquele 
com quem fala, escuta pacientemente e criticamente o discurso do outro. (FISCHER; LUSAD in STRECK et al, 2008, p. 301).

Eles e elas têm seus anseios, esperanças e projetos; e abrem pequenas "brechas" dentro do sistema socio-político-econômico, criando elementos para que possam permanecer dentro da vida. Entre esses elementos está a inserção nos movimentos sociais populares, nos quais pouco a pouco vão se criando formas de identificar seus saberes e expressões de competências, numa forma de protagonismo. Ao falar sobre esta inserção do adolescente e do jovem, enquanto Sujeitos Sociais, CUSSIANOVICH (1999) aponta o protagonismo como importante categoria na história sócio-cultural da criança e destaca seus cinco elementos importantes:

- Protagonismo como um Direito Humano;

- Protagonismo como expressão de solidariedade;

- Protagonismo é independente de idade;

- Protagonismo enquanto conceito e eixo prático da participação;

- Protagonismo enquanto exercício de organização.

Aqui, quer se entender o protagonismo das crianças, adolescentes e jovens como expressão de suas críticas sobre estrutura social, criando formas e soluções para seus problemas.

Entre los factores que han permitido la emergencia de ciertas expresiones de protagonismo de los niños y adolescentes trabajadores en América Latina podemos señalar: - La irrupción de las organizaciones populares como actores sociales; el protagonismo de la mujer popular organizada en la vida cotidiána de las poblaciones; los movimientos sociales en favor de la infancia en los últimos 15 años y su impacto en la defensa de los derechos del niño; las germinales experiencias de organización de los niños trabajadores de la década de 70 como el Manthoc en Perú, etc. y el esfuerzo por acompañar estas experiencias con una reflexión teórica. (MNNATSOP 1997, p. 90).

Dentro do processo da luta pela sobrevivência, adolescentes e jovens, sobretudo em países da América Latina, vão elaborando e expressando diferentes formas de verem a si mesmos e o mundo que os cerca. Neste processo, o debate latinoamericano sobre o protagonismo infanto-juvenil vem ganhando gradativamente seu espaço e possui seus primeiros momentos concretos nos fins dos anos 70. Como exemplo, podemos citar o Movimiento de Niños Trabajadores Hijos de 
Obreros Cristianos MANTHOC, do Peru, que nasceu dentro do movimento da juventude trabalhadora em 1976.

Este protagonismo possui suas raízes, sobretudo, no protagonismo das classes populares organizadas na América Latina e está ligado, como aludimos acima, às novas correntes pedagógicas que se concretizam:

- na Pedagogia da Libertação;

- no surgimento dos movimentos sociais;

- na Teologia da Libertação;

- na organização de adolescentes e jovens trabalhadores.

Dentro desta perspectiva, surge um novo olhar em torno da infância, adolescencia e juventude, de perceber que, por exemplo, a luta por uma Pedagogia dos Direitos Humanos não é monopólio dos adultos; que crianças, adolescentes e jovens estão, a cada dia, construindo a necessidade de refletirem sobre suas experiências de vida. Antes, uma das grandes motivações eram as condições de trabalho e, hoje, outros focos foram descobertos, como é o caso da luta pela produção cultural, políticas públicas e sociais, lazer, moradia, etc.

[...] hablar de protagonismo infantil, de organización de los niños trabajadores, de los niños como sujeto y movimiento social significa romper con los esquemas dominantes, con prenociones y prejuicios fuertemente enraizados. Significa poner de cabeza la relación entre adulto y niño, proyectar un modelo de niñez totalmente diferente, en fin cuestionar radicalmente "la exaltación de la infancia como período de protección y preparación a la vida“ exaltación que „permite privatizar al niño, confinarlo al ámbito de la familia, de la pequeña vecindad; permite oír su tono de voz para no escuchar el mensaje de su palabra" (CUSSIÁNOVICHv).

Nesse sentido, podemos abaixo destacar algumas características desse protagonismo.

- Participação em ações que dizem respeito a problemas relativos ao bem comum, na escola (grêmios estudantis, conteúdos escolares cada vez mais relacionados à experiência de vida dos adolescentes e jovens), na comunidade ou na sociedade mais ampla - como exemplo, podemos citar a iniciativa de uma professora de História em uma escola pública da cidade de Caruaru que estimulou seus alunos a escreverem a história do bairro no qual a escola está localizada. Nesta ação os alunos passaram a 
conhecer melhor as necessidades, avanços e as histórias dos personagens do bairro;

- Participação na organização e planejamento das atividades, no que envolve o conhecimento relacionado, da execução, dos resultados, e como exemplo, pode-se citar a participação de educandos e educandas na elaboração dos programas de atividades socioeducativas (oficinas de arte, música, artesanato, horticultura, etc.);

- Passagem da mensagem da cidadania criando acontecimentos em que a criança e os adolescentes ocupam uma posição de centralidade nas quais os(as) adolescentes e jovens partilharam os diversos olhares em torno dos bairros em suas histórias, necessidades e possibilidades de enfrentamento da falta de condições de vida (carta ao prefeito, elaboração de um informativo sobre cidadania, etc.);

- Formar superior de educação para a cidadania não por palavras, mas pelo curso dos acontecimentos - p. ex. através da participação de educandos e educandas em seminários e fóruns municipais de defesa dos direitos da criança e do adolescente, participação nas manifestações públicas como GRITOS DOS EXCLUÍDOS, MARCHAS CONTRA A REDUÇÃO DA MAIORIDADE PENAL, etc.;

- Protagonismo concebe o adolescente e o jovem como fonte de iniciativa, que é ação; como fonte de liberdade, que é opção; e como fonte de compromissos, que é responsabilidade, por exemplo, na participação de assembléias avaliativas nos projetos sócio-educativos, na montagem de informativos, jornais, encontros de formação exclusivos para os adolescentes e jovens, etc.;

- É um tipo de intervenção no contexto social para responder problemas reais em que a criança e o adolescente são atores principais.

Os aspectos, citados acima, surgiram do diálogo entre educadores e educadoras sociais, educandos e educandas nos vários momentos de partilha de saberes, dentro dos espaços escolares e não escolares. Entre esses momentos podemos citar os Encontros Nacionais do Movimento de Meninos e Meninas de Rua, dos Seminários da Pastoral do Menor da CNBB, dos cursos de formação de educadores sociais, dos encontros de formação para meninos e meninas em projetos comunitários etc. 


\section{Dando-se conta da rua enquanto espaço de atuação}

Ao refletir em torno da leitura do protagonismo infanto-juvenil, enquanto expressão de uma Pedagogia Social, e elemento na formação dos educadores e educadoras sociais, partimos de uma das ideias do pensador Paulo Freire em torno do dar-se conta da criança, do adolescente e dos jovens como sujeitos sociais e culturais.

Nesse processo de dar-se conta, podemos destacar alguns cenários, cujos elementos e acontecimentos presentes, favorecem a discussão e análise dos adolescentes e jovens, em condições de pobreza, como sujeitos sociais e protagonistas. Estes cenários são de importância fundamental no processo do dar-se conta do educador e da educadora social e do voluntário em torno da experiência do protagonismo. Podemos destacar alguns cenários importantes desta trama:

- Nas condições de vida;

- Na experiência de vida junto aos educadores dentro dos Movimentos Sociais Populares;

\section{Em suas condições de vida}

Não se pode discutir sobre protagonismo infanto-juvenil no que se refere ao seu dar-se conta, sem uma atenção ao processo sócio histórico da sociedade globalizada e capitalista, sobretudo o desenrolar dos acontecimentos na sociedade brasileira.

Diferentemente do caso europeu, a expansão capitalista brasileira, no século XIX não incorporou suficientemente os grupos proletários adultos disponíveis nas cidades, nem os liberados pelos setores produtivos estagnados, como na agricultura. Ao contrário, desarticulou a produção rural e a pequena indústria familiar, desestabilizando a vida das populações ligadas a essas atividades e incrementando a migração interna, em busca de oportunidades que a cidade não tinha condição de oferecer satisfatoriamente. (SILVA, 2001 p.14).

A participação coercitiva, sobretudo dos adolescentes e jovens brasileiros no mundo do trabalho, teria que extravasar das fábricas para os espaços públicos, transformando-se, com isso, os filhos dos trabalhadores em "meninos e meninas NA, e DE, rua. O conceito de Meninos e Meninas de Rua é um dos mais 
ambíguos e de difícil manejo analítico-operativo, pois abarca um conjunto de situações muito diferenciadas, segundo Schibotto, 1990.

Atualmente eles estão nas ruas e praças das grandes e pequenas cidades, tanto no campo como no espaço urbano, junto ao outros andarilhos e andarilhas. $\mathrm{Na}$ andarilhagem ${ }^{\text {vi }}$ pelas ruas, vão fazendo de tudo: produzem pequenos objetos, catam material reciclado (papel, vidros, latas etc.), vendem bombons, flores, santinhos e bugigangas; engraxam sapatos, lavam e tomam conta de automóveis em estacionamentos etc. Elas e eles se viram. Jogam futebol, brincam de esconder. Dormem na calçada, fogem da polícia. Estão nas ruas.

\section{O Contexto da Situação de Rua de crianças, adolescentes, jovens}

Segundo os estudos atuais em torno dos que andarilham nas ruas, o estar nesse espaço não é um movimento atual na sociedade. Percorrer distância, migrar, perambular, não possuir residência fixa é uma dinâmica social relatada desde a Grécia antiga. Podemos destacar a figura do filósofo mendigo Diógenes de Sínope, que viveu entre os anos de 404-323 a.C., muito embora ele não possa ser tomado como referência da situação de rua que se vive hoje. Atualmente, a situação de exploração capitalista do trabalho, as desapropriações de terras, a concentração de renda são fatores intrínsecos ao aumento da pobreza e da situação de rua.

No entanto, a história de Diógenes convida à reflexão acerca do incômodo que ele trazia na sociedade grega e de suas questões existenciais: ao questionar as instituições sociais e os preceitos do cidadão da polis, Diógenes pode tornar-se um símbolo que nos remete ao incômodo da situação de rua contemporânea. Diógenes encarna a antítese de nossa organização social, colocando-nos questões para reflexão acerca de nosso atual período. (BRASIL, SDH, 2013, p.08).

Nas ruas, muitas vezes, dormem, trabalham, amam, roubam, comem, andam sem rumo, brincam, apanham, vivem e morrem. A rua aparece como um espaço, em que, muitas vezes, é possível retirar aquilo que Ihes foi tirado e negado pela estrutura social. São estas cenas que podem ser vistas ao se caminhar pelas ruas, tanto dos grandes centros urbanos como no espaço do campo, dando, 
assim, o sinal de que a presença de adolescentes e jovens em situação de rua não é mais um fenômeno característico dos grandes centros urbanos.

Entretanto, pensa-se, muitas vezes, que estar na rua é estar fora da casa, portanto sem laços familiares; é estar fora do mercado de trabalho. Nesse sentido, a rua sempre é pensada como um 'estar fora'. Esta mesma lógica, representa as crianças, adolescentes e jovens.

São chamados de: "pivetes", moleques, trombadinhas; cheira cola, menores de rua, marginal, malandro, meninos e meninas de rua, pibes, riesgo cien, gurises, chiquilines, callejeros, petisos, piranhas, pajeros fruteros, polilas, guambras, gamines, chinos, pelaos, chiquillos, cipotes, quinchos, güirros, bichos, patojos, chavos, pelones, palomos, etc (LIEBEL, 1994, p. 14).

Embora a experiência nas ruas possua uma marca de extrema marginalização, os que transitam por ela não podem ser tomados enquanto 'fora' da realidade. Estar na rua não significa, de modo algum, a não existência de outros referenciais, sobretudo de família, de casa, de escola, da comunidade. Muito pelo contrário, pode significar, de início e no processo de aprendizagem que nela se desenrola, a busca de alternativas à precariedade desses espaços.

Defendemos ser vital para esse olhar o ter contato com as criações dos que andarilham nas ruas. No ano de 2014 ocorreram as comemorações pela passagem dos cem anos de nascimento uma personagem que em muito contribuiu para uma leitura do que está por dentro, e por trás, das ruas e das periferias urbanas; estamos falando de Maria Carolina de Jesus. Com sua principal obra "Quarto de Despejo" ela realiza uma leitura do cotidiano.

\section{7 de junho de 1958}

Nós somos pobres, viemos para as margens do rio. As margens do rio são os lugares do lixo e dos marginais. Gente da favela é considerada marginal. Não mais se vê os corvos voando as margens do rio, perto dos lixos. Os homens desempregados substituíram os corvos (...). Escrevo a miséria e a vida infausta dos favelados. Eu era revoltada, não acreditava em ninguém. Odiava os políticos e os patrões, porque o meu sonho era escrever e o pobre não pode ter ideal nobre. Eu sabia que ia angariar inimigos, porque ninguém está habituado a esse tipo de literatura. Seja o que Deus quiser, Eu escrevi a realidade.(JESUS,1993, p.37). 
A partir desses aspectos, defendemos que educadores e educadoras sociais precisam estar atentos em aguçar a sensibilidade e intimidade junto aos saberes que são produzidos pelos diversos atores sociais e que são a base para a construção de uma proposta socioeducativa que venha a transformar a vida dessas crianças, adolescentes e jovens em situação de rua e vulnerabilidade pessoal e social.

\section{Paulo Freire e os Educadores Sociais: possibilidades de uma proposta alter(n)ativa no mirar a criança e o adolescente enquanto protagonistas na ação socioeducativa}

No início dos anos 80, eram poucas as oportunidades ou reflexões que pudessem ajudar os educadores e educadoras sociais a refletirem suas práticas e construirem uma proposta educativa centrada na necessidade dos educandos e educandas. Foi entao que, em meados de 1983, Paulo Freire passou a se encontrar com Educadores e Educadoras Sociais que atuavam no atendimento a crianças, adolescentes e jovens em situação de pobreza no Brasil.

$\mathrm{O}$ momento era $\mathrm{o}$ de refletir e construir com os educadores e educadoras (que tanto influenciaram as propostas alternativas de atendimento à criança e ao adolescente), novas possibilidades de enfrentamento da situação de marginalização na qual as crianças, adolescentes e jovens se encontravam. Naquela ocasião, ele chamava atenção para a construção de uma nova postura educativa dos educadores e educadoras sociais no trabalho junto às crianças, adolescentes e jovens que, pouco a pouco, se descobriam enquanto sujeitos sociais e protagonistas na ação sócio-educativa.

A partir daquele momento, educadores e educadoras sociais embarcavam num processo de elaboração/criação constante de suas vidas, de suas práticas; vendo e revendo, fazendo e refazendo princípios educativos voltados a um atendimento não paternalista, mas e, sobretudo, libertador. Esse processo procura tomar como ponto de partida o Pensar a Prática do cotidiano tanto nas situações de Rua, como dentro dos Projetos Sócio-Educativos. Nesta convivência, educadores e educadoras iam construindo condições para efetivar situações grupais autênticas em que se pudessem captar as expectativas, histórias de vida, valores etc., através da real participação da Meninada. Como 
ilustração, têm-se os seminários organizados em várias regiões do Brasil por educadores e coordenadores de projetos sócio comunitários. Surgia também o Movimento Nacional de Meninos e Meninas de Rua, a Pastoral do Menor, e aqui no agreste pernambucano o MACA, Movimento de Apoio às Crianças e Adolescentes, cuja atividade principal era a de realizar um intercâmbio entre educadores e educadoras, no qual as experiências cotidianas do atendimento eram pensadas com o apoio de leituras, no campo da educação em particular. Educadores partilhavam e aprofundavam as experiências no campo da educação artística, da escolarização, da horticultura e criação de pequenos animais, da orientação e iniciação profissional, etc. Os encontros ocorriam dentro dos projetos sócio comunitários o que dava oportunidade aos educadores em pensar em uma prática, concretamente, vivenciada.

Passados trinta e um anos, a participação ativa das crianças, adolescentes e jovens no processo educativo vêm se tornando um elemento presente e que vem colaborando, levantando novos olhares em torno da formação do educador e daseducadora social, no sentido de perceberem a necessidade de se identificarem com as necessidades dos adolescentes e jovens, sem perder sua individualidade, buscarem com eles e elas as propostas para suas inquietações do, existir no mundo', fazendo a história com as crianças, os adolescentes e os jovens.

Necessário se torna ao educador e a educadora perceberem que a Rua não é só medo e também não é só brincadeira. A criança, adolescente e o jovem, efetivamente, têm de se 'virar', aprender a se 'safar' e a se 'sustentar'. Conquistar o ponto de venda, travar relações amigáveis ou não, com outras crianças (e mesmo com adultos) que com ela disputam o espaço; se inserir, ou não, em atividades ilícitas, lidar com a pressão dos órgãos repressivos, lidar com a identidade marginal criada que ela sente no olhar das pessoas. Por outro lado na sociedade capitalista industrial, a rua deixa de ser um lugar comum, espaço geral de sociabilidade para se restringir a um espaço monofuncional, destinado à circulação. $O$ espaço de socialização livre da rua é substituído pelo das instituições, sobretudo, da escola. 


\section{Procurando dar-se conta da cotidianidade de vida nas ruas}

Para enfrentar este espaço resta, sobretudo, às crianças, adolescentes e jovens, desenvolverem estratégias de sobrevivência. Como destacou Paulo Freire em sua conversa com os educadores e educadoras sociais,

Quem vive sob o ataque generalizado, metido num terreno como esse, ou inventa manhas de defesa, entre elas a da "insensibilidade", ou não sobrevive. Para sobreviver tem que robustecer a pele, a mente, a emocionalidade. É preciso, então entender o jogo de manhas fundamentais, que são as expressões das resistências, que as crianças têm que criar para poderem sobreviver enquanto presenças no mundo. (FREIRE 1985, p. 20).

É preciso, sobretudo, entender a cotidianidade da rua, a cotidianidade do perambular dessas crianças, adolescentes e jovens. Os autores alemães Manfred Liebel e Uwe von Dücker, acadêmicos militantes na causa da criança e do adolescente e da pedagogia social, sobretudo em países da América Central e Latina, apontam significativas contribuições para analisar e discutir a rua enquanto espaço que possibilita a geração de propostas educativas que tomam as crianças, adolescentes e jovens como atores sociais. No caso de Uwe von Dücker (1996), ele destaca que o importante é que as crianças, adolescentes e jovens se tornem totais participantes na construção de sua nova vida. Se queremos tirá-los das ruas, é preciso que elas participem ativamente no desenrolar desse processo.

Enquanto as condições socioeconômicas da sociedade não mudarem essencialmente, a construção de uma proposta de trabalho social precisa ter como ponto de partida a vida real, das condições dadas, dos saberes instituídos pelo grupo, e a proposta pode ser orientada nas seguintes teses:

a. A criança, o adolescente e o jovem devem aprender a sobreviver de forma humana no espaço da rua;

b. O adulto precisa estar junto e assumir seu papel de acompanhante e animador;

c. O adulto deve entender a experiência de vida das crianças, adolescentes e jovens nas ruas; 
d. O adulto deve estar preparado para aprender com as crianças, os adolescentes e jovens e por último;

e. A criança, o adolescente e o jovem precisam participar plena e ativamente na construção de suas vidas vii.

\section{Uma outra pedagogia é possível: A Pedagogia Social no contexto do Protagonismo Infanto-Juvenil}

Nesse sentido, para os educadores e educadoras sociais, o entendimento da dinâmica da rua e da experiência social vivida pelas crianças, adolescentes e jovens em situação de rua e vulnerabilidade pessoal e social, bem como a dinâmica construída dentro de socioeducativos é fundamental. Destaca-se aqui a necessidade de problematizar o cotidiano desta meninada nas ruas. Sobre este aspecto, Paulo Freire destaca que "a ação de educar tem necessariamente um ponto de partida que é o de ter a compreensão da criança, do adolescente e do jovem em sua própria cotidianidade, enquanto certa classe social, seus valores, aspirações, medos, etc. [...] é importante que se compreenda, por exemplo, o que é que se está dando dentro desta cotidianidade" (FREIRE 1985, p. 20).

Dentro desta mesma reflexão, é possível problematizar e tematizar a rua tomando-a como ponto de partida e não de chegada, enquanto espaço onde é possível construir uma proposta pedagógica, a chamada Pedagogia da Rua (Straßenpädagogik), que nasce do processo da educação popular e de um entendimento da andarilhagem das crianças, adolescentes e jovens pelas ruas, e as estratégias encontradas por eles para enfrentar a situação de marginalidade. Um dos princípios básicos para isso, como aponta Dücker (1996), é a criança, o adolescente e o jovem problematizarem, tematizarem a vivência nas ruas. Eles devem refletir a própria experiência de vida e aprender a formular possibilidades de intervenção, com o apoio e presença dos educadores nas ruas. viii 


\section{Algumas questões e lugares da Pedagogia Social sobre o pensar o protagonismo infanto-juvenil e o trabalho socioeducativo}

De uma forma geral, a Pedagogia Social é uma disciplina pedagógica ou se refere a uma das Ciências da Educação. Para Romans; Petrus e Trilla:

Pedagogia social é, pois, um conjunto de saberes, seja teórico, técnicos, experienciais..., descritivos ou normativos..., mas saberes que tratam de um objeto determinado. Este objeto é o que chamamos educação social. (2003, p.16).

A Pedagogia Social implica um conhecimento do indivíduo para melhor poder atuar sobre ele, quer numa situação normalizada, quer numa situação de conflito ou de necessidade. O conceito de Pedagogia Social mais generalizado é o que faz referência à ciência da educação social das pessoas e grupos, daí sua importância na investigação em torno dos processos participativos de produção de saberes, protagonizados por crianças, adolescentes, jovens em projetos sócio-educativos ou no espaço das ruas. Entendemos a Pedagogia Social como um projeto de sociedade, no qual todos os espaços e todas as relações sejam, essencialmente, pedagógicas, possibilitando a construção do educando e da educanda enquanto sujeitos sociais e protagonistas.

A Pedagogia Social tem seus primeiros passos na Alemanha no surgimento da sociedade urbano-industrial e empapada por uma multiplicidade de contribuições teórico-metodológicas, sorbetudo por estar preocupada com a educabilidade do ser humano em sua experiencia social. Nesta época a educação era tomada como uma solução para os problemas humanos e sociais - as necessidades individuais e sociais em decorrencia dos fortes movimentos migratórios, proletarização do campesinato, desemprego, pobreza, exclusão econômcia e cultural, abandono de crianças e adolescentes, deliquencia juvenil, entre outros. Delimitanos nossa curta discussão a partir da Pedagogia Social alemã na qual podemos identificar dois momentos:

\section{PRIMEIRAS DISCUSSÕES}

\section{Autores - primeiros passos}

- Adolph Diensterweg (1750 a 1866)

- Paul Natorp (1854 a 1924)

- Herman Nohl (1879-1960) 


\section{Características do Pensamento}

- Promover decisões independentes e ação de auto-responsabilidade para os indivíduos;

- Resolução de conflitos sociais;

- Integração social, as pessoas sociais e ou pessoalmente desfavorecidas ou com deficiência;

- Entende a pedagogia social como um conceito ordenado, integração de esforços para a abertura de novos caminhos educativos e formas de ajuda à integração social da juventude;

- Ao contrário de Natorp, a pedagogia social é apenas uma parte ou espaço da pedagogia geral, com fins específicos no sentido da formação popular. Assinala a necessidade de dedicar recursos à prevenção, ajuda e recuperação da juventude;

- Toma a realidade concreta como ponto de partida da teoria da pedagogia social;

- Perseguir o bem do sujeito, desenvolver as suas capacidades e também a sua vontade;

- Realça a necessidade de modificar as condições ambientais e contextuais, com o fim de assegurar a eficácia da ação pedagógica social;

- Destaca a tarefa de formação e investigação inerente à pedagogia social.

- Sublinha a necessidade de realizar ações científicas que contribuam para dotar e estatuto científico a pedagogia social, até então considerada apenas no quadro conceptual;

\section{POR UMA PEDAGOGIA SOCIAL CRÍTICA}

Autor:

- Klaus Mollenhauer (1928-1998)

\section{Características do pensamento}

- Deve partir da situação concreta;

- Dá importância às diferenças culturais e tem em conta a memória histórica;

- É autocrítica e usa a reflexão do coletivo como critério de valoração da prática;

- Parte de pressupostos emancipatórios;

- Usa a investigação como estratégia metodológica;

- Analisa e reflete sobre a observação para transformar a realidade.

Em se tratando de uma Pedagogia Social Latino-Americana, a mesma é tecida a partir do contexto de uma pedagogia latino americana. Nesse sentido temos a grande contribuição dos estudos realizados por Danilo Romeu Streck. Em seu livro Fontes da Pedagogia Latino Americana - uma antologia, Streck (2010), apresenta a necessidade de contribuir para a reconstrução de uma teoria 
pedagógica que, ao olhar para trás e reencotnrar-se com a sua memória, possa, ao mesmo tempo, se abrir para novos horizontes do presente.

[...] por ser herdeira de uma determinada formação histórica e cultural, forjou-se, nesta parte do mundo, um pensamento com algumas características próprias, em princípio, nem melhor nem pior que o pensamento em outros lugares. Mas é um pensamento que, em meio à fugacidade das ideias de fora que, como ondas, se sucederam em modas, busca encontrar raízes por onde continua subindo a seiva que, mesmo imperceptível, continua alimentando práticas e esperanças. (STRECK, 2010.p 20).

O autor apresenta vinte seis autores e autoras que possuem uma genuína busca pela emancipação do povo através da educação popular, como citamos anteriormente neste artigo, e entendemos que esta é uma significativa contribuição no cenário de uma pedagogia social latino americana. Entre os autores e autoras podemos citar: O povo Guarani, Simón Rodríguez, Andrés Bello, Nísia Floresta, José Pedro Varela, José Marti, José Vasconcelos, Maria Lacerda de Moura, Gabriela Mistral, José Carlos Mariátegui, Anísio Teixeira, Monsenhor Romero, Florestan Fernandes, Paulo Freire, Darcy Ribeiro, Orlando Fals Borda, Frantx Fanon, Che Guevara, Chico Mendes, Subcomandante Marcos.

Pensar a Pedagogia Social no contexto dos estudos sobre pedagogia latinoamericana, sugerida por Streck, é um caminho interessante, pois ele nos ajuda a pensar estas conexões ao apontar que

A complexificação da sociedade exige que a pedagogia aceite 0 desafio de recriar-se em novos contextos sociais, econômicos e culturais. A origem da pedagogia social, como uma disciplina e como campo de atuação, é referida à revolução industrial no século XIX que provocou mudanças na estrutura da sociedade e que tiveram profundos impactos na vida das pessoas. Hoje efeitos de outras e novas mudanças não causam menos impacto sobre o indivíduo e no tecido social. (STRECK, 2012, p.35).

Por isso, Graciani (1997) ao discutir a Pedagogia Social de Rua, aponta a necessidade de refletirmos em torno das caracteristicas apresentadas pela sociedade e a própria Rua, enquanto espaço contruído pelos sujeitos sociais que pedem outra forma de pensar a pedagogia.

Vejo que a pedagogia social tem a possibilidade de inserir-se em diversos espaços do tecido social ou das redes sociais e operar 
as transformações de dentro destes espaços. Isso implica um conhecimento aprofundado do funcionamento e da estruturação da sociedade e, ao mesmo tempo, da formação e atuação dos sujeitos dentro da sociedade. (STRECK, 2012, p.36).

Seria impossível pensarmos uma Pedagogia Social Latino-americana desconectada da Educação Popular (enquanto uma proposta teóricometodológica), pois esta é fundamental para que seja possível traçar algumas diretrizes a serem levadas em conta para a construção de um projeto de Pedagogia Social Latino-Americana, que para STRECK deve levar em conta alguns importantes elementos, entre eles podemos destacar:

- A prática social como ponto de partida para tarefa educativa;

- A leitura estrutural da sociedade, buscando identificar as relações de poder e as possibilidades de transformação;

- A crença no potencial transformador dos sujeitos que se situam à "margem" das estruturas hegemônicas;

- O reconhecimento da pluralidade de conhecimentos, saberes, racionalidades e sentimentalidades;

- A construção de metodologias participativas, tendo o diálogo como princípio metodológico central.

$\mathrm{Na}$ construção de um projeto de Pedagogia Social Latino Americana podemos também tomar acontribuição de Paulo Freire como um importante pensador da Pedagogia Social, pois o mesmo recomendou aos educadores brasileiros: "Escrevam pedagogias e não sobre pedagogias", incitando-os a desenvolver métodos e técnicas adequadas para lidar com a diversidade da população brasileira e de suas experiências. A Pedagogia Social no Brasil, com sua base teórico-metodológica ainda em construção, mas com forte inspiração na Educação Popular, é necessária para dar conta dos novos paradigmas instituídos para atender demandas e necessidades dos novos sujeitos sociais trazidos à luz pelas transformações sociais ocorridas após a democratização do país e inscritos na Constituição Federal de 1988, tais como a população indígena, os remanescentes quilombolas, a população rural, a mulher, a criança e o adolescente, o idoso, o apenado, a população de rua e os portadores de necessidades educativas especiais, entre outros. 


\section{Os Educadores e Educadoras Sociais indo para além da cotidianidade}

A partir dos aspectos já colocados, consideramos que o entendimento por parte dos educadores e educadoras sociais, de que o trabalho educativo a ser feito com as crianças, adolescentes e jovens é de caráter político, ideológico e pedagógicoix. Segundo Silva, 1989, O fato dos educadores perceberem que a realidade de vida das crianças e dolescentes marginalizados está relacionada com a situação: sócio-política-econômica-social brasileira e levou à formação dos mesmos, na estruturação dos objetivos, conteúcos e metodologias, a possuir um caráter político. Isto é, uma formação baseada na realidade sócio-políticaeconômica-cultural, levando a uma interferência, através da ação dos educadores, nos instrumentos geradores da marginalização da criança.

Isto se torna condição fundamental para que os mesmos percebam que a problemática das crianças, adolescentes e jovens marginalizados não pode ficar apenas resumida a uma ocupação de trabalho produtivo, uma formação profissional, uma atividade de atendimento, escolarização que, muitas vezes, pode significar um paternalismo, assistencialismo, sem haver uma reflexão em torno dos acontecimentos do cotidiano. Por detrás da vida de sofrimento e miséria em que vivem as crianças, adolescentes e jovens, existe um mundo que gera certos valores; certas crenças; certos fazeres.

Por estarem nas ruas, becos e praças cometendo as mais diversas "trelas", as crianças, adolescentes e jovens em situação de rua e vulnerabilidade pessoal e social, estão em um mundo que não é o mundo do educador, e inevitavelmente, há um choque que leva o educador a se colocar numa postura de querer converter o mundo dos meninos e meninas de rua sem antes haver um processo reflexivo e crítico. Para Paulo Freire, "quando se pensa em converter o outro é porque temos um ponto de partida, que é o seguinte: onde se está é melhor, o que a gente é, é melhor, senão não haveria porque converter o outro" (FREIRE, 1985, p. 12).

Isto nos leva a pensar o processo de construção de uma Pedagogia Latino Americana, à qual a pedagogia social vem se conectando, empapada pelo pensamento pedagógico freireano. Ainda segundo Freire, esta tarefa para 0 
educador e para a educadora sociais, enquanto facilitadores do processo educativo, não é fácil, pois:

demanda sensibilidade social e histórica (...) ao lado do entendimento cientificamente rigoroso da realidade que ensina ao educador a compreender certas formas de comportamento de pura rebeldia ou de outro fatalismo entre os oprimidos para, com eles, tentar a sua superação (...) pois o nosso amor por esses meninos negados no seu direito de ser, só se expressa autenticamente quando nosso sonho é o de criar um mundo diferente.(ibid., p. 13).

O compreender a cotidianidade não é um simples conversar com os educandos sobre as atividades desenvolvidas, mas especialmente dar-se conta do educando, "o ir além dele". O perguntar-se quem é essa criança, adolescente e jovem e o que ela significa para o educador, educadora, voluntário e voluntária. Para Freire, nesse momento, a mente da meninada muda de atitude, muda de postura, muda de posição com relação ao comportamento da mente no normal, no cotidiano. Quer dizer, a mente se enquadra numa posição de quem quer conhecer.

Nesse sentido, é preciso imergir no cotidiano do educando (da criança, do adolescente e jovem de rua, que está diante do educador confeccionando um objeto, realizando uma atividade de escolarização, horta, arte, lazer, esporte, etc). Entretanto, jamais poderemos ficar nele. Devemos mergulhar no mundo cotidiano para sair dele com a meninada, numa compreensão destes enquanto participantes de uma classe social, com seus valores, aspirações, medos etc. Acreditamos, portanto, que todos esses elementos devem estar presentes nos princípios que orientam uma proposta formativa para educadores, educadoras sociais a partir de uma Pedagogia Social Latino Americana, que gera condições para pensar as experiências sociais tecidas pelas crianças, adolescentes, jovens, adultos e idosos nos processos participativos de produção de saberes.

\section{Considerações finais}

Resta agora, tentar perceber, na prática histórica de um projeto de atendimento sócio-educativo, a presença e o movimento desses elementos pensados por Paulo Freire e por outros pensadores comprometidos com a elaboração de uma 
prática educativa direcionada à transformação da realidade com os oprimidos a partir também de uma Pedagogia Social Latino Americana. Sabe-se, contudo, como Paulo Freire, que as práticas libertadoras estão sujeitas a limites, e é a própria experiência que ensina, pois "muitas vezes se faz o que se pode e não o que se gostaria de fazer. Há limites econômicos, limites ideológicos, sociais, limites históricos" (FREIRE 1985, p. 22).

Nesse sentido, ao chegar aos últimos parágrafos deste artigo, desejamos apresentar a nossa intenção de realizar um estudo (o projeto de pesquisa está em elaboração), em torno da experiência da Pedagogia Social em um projeto sócio-educativo com adolescentes e jovens em situação de rua e vulnerabildiade social em uma cidade no agreste pernambucano e outro em uma cidade alemã. No agreste, o projeto selecionado é o Centro de Educação Popular Comunidade Viva - COMVIVA ${ }^{x}$ que, desde 1989, vem tecendo possibilidades de uma pedagogia sob a ótica dos educandos e educandas. Na cidade alemã o projeto ainda está definindo o espaço de pesquisa.

Esperamos com este estudo vir a contribuir com os fundamentos teóricometodológicos de uma pedagogia social emancipatória, que pensa os processos participativos de produção de saberes na ótica de uma Educação Popular, auto determinada pelos sujeitos que dela fazem parte, em nosso caso pelos adolescentes e jovens em situação de risco e vulnerabilidade social.

\section{Referências}

ALVAREZ, Carlos Gonzales :Bewusstseinsarbeit mit arbeitenden Kindern. In: DEWES / HOLM Neue Methoden der Arbeit mit Armen - Am Beispiel Straßenkinder und arbeitende Kinder. Frankfurt, 1996.

BRANDÃO, Carlos Rodrigues. Andarilhagem In: STRECK, Danilo R. RENDIN, Euclides, ZITIKOSKI, Jaime José. Belo Horizonte: Autêntica, p. 40, 2008.

BRASIL, Câmara dos Deputados. Estatuto da Criança e do Adolescente. Brasília, 1990.

BRASIL, Secretaria de Direitos Humanos da Presidência da República. Diálogos sobre populações em situação de rua no Brasil e na Europa: experiências do Distrito Federal, Paris e Londres/ Secretaria de Direitos Humanos da Presidência da República, Brasília, SDH, p. 08, 2013. 
CALDART, Roseli Salete. Pedagogia do Movimento Sem Terra. Petrópolis, 2000.

CAMPOS, André et alii (Orgs.). Atlas da exclusão social no Brasil. 2 Vol. São Paulo, 2003.

CARRILLO, Alfonso Torres. Lá Educación Popular - trayectoria y actualidad. Bogotá, Editorial El Búho, 2007.

CONGRESSO NACIONAL. Relatório Final da Comissão mista especial destinada a estudar as causas estruturais e conjunturais das desigualdades sociais e apresentar soluções legislativas para erradicar a pobreza e marginalização e reduzir as desigualdades sociais e regionais. Brasília,1999.

COSTA, Antônio Carlos Gomes da: Infância, juventude e política social no Brasil. In: Brasil: Criança Urgente: A lei 8069/90. O que é preciso saber sobre os novos direitos da criança e do adolescente. São Paulo, p. 38-41, 1990.

CUSSIÁNOVICH, Alejandro. Was ist Protagonismus? In: LIEBEL, Manfred; OVERWIEN, Bernd / RECKNAGEL, Albert (Orgs.): Was Kinder könn(t)en Handlungsperspektiven von und mit arbeitenden Kindern. Frankfurt, p. 39-53,1999.

DEWES, Jürgen / HOLM, Karin (Orgs.). Neue Methoden der Arbeit mit Armen. Am Beispiel Straßenkinder und arbeitende Kinder. Frankfurt, 1996.

DÜCKER, Uwer von. In extremer Armut, in extremem Reichtum und auf der Straße lebende und arbeitende Kinder bei Entwicklung eigenständiger Kulturmerkmale. In: DEWES / HOLM (1996), Frankfurt, p. 53. 1996.

FISCHER, Nilton Bueno; LUSADA Vinícius Lima. Ouvir. In: STRECK, Danilo R. RENDIN, Euclides, ZITIKOSKI, Jaime José. Belo Horizonte: Autêntica, p. 301, 2008. FREIRE, Paulo. Educação e Mudança. São Paulo, 1985.

GRACIANI, Maria Stela Santos. Pedagogia Social de Rua. São Paulo, 1997.

JESUS, Carolina Maria de. Quarto de despejo: diário de uma favelada. São Paulo: Editora Ática. 1993.

KRAMER, Sonia / LEITE, Isabel (Orgs.). Infância: fios e desafios da pesquisa. São Paulo, 2001.

LIEBEL, Manfred. Mala Onda - Wir wollen nicht überleben, sondern leben. Frankfurt, 1990.

LIEBEL, Manfred. Wir sind die Gegenwart. Kinderarbeit und Kinderbewegung in Lateinamerika. Frankfurt, 1994.

LIEBEL, Manfred. Kinderbewegungen in Lateinamerika. In: DEWES / HOLM. Frankfurt p. 78,1996.

MNNATSOP. Niños trabajadores y protagonismo de la infância. Lima,1997.

RIBEIRO, João Ubaldo. Viva o Povo Brasileiro. 14 edição. São Paulo: Nova Fronteira, 1984. 
SADER, Emir. Democracia é coisa de gente grande? In: SADER, Emir et alii Fogo no pavilhão, uma proposta de liberdade para o menor. São Paulo, 1987. SCHIBOTTO, Giangi. Niños Trabajadores - Construyendo una identidad. Lima, 1990.

SILVA, Alexandre Magno Tavares da. A Experiência de vida de crianças e adolescentes em situação de pobreza no cotidiano social: ser protagonistas? In: Revista Interfaces de Saberes, p. 11-28, 2001.

STRECK, Danilo R. (Org.) Fontes da pedagogia latino-americana: uma antologia. Belo Horizonte: Autêntica, 2010.

STRECK, Danilo R. Ligações esquecidas: requisitos para uma pedagogia social latino-americana. Revista Diálogos: pesquisa em extensão universitária. IV Congresso Internacional de Pedagogia Social: domínio epistemológico. Brasília, v.18, n.1, dez, 2012.

VIGOTSKI, Lev S. A Formação Social da Mente. São Paulo, 1999.

i Participavam deste coletivo as seguintes instituições e grupos: PROART/JUMA (Carpina), Ação Paroquial de Assistência (Carpina), Centro Social Madre Virginia (Carpina), Lar Dom Bosco (Carpina), SERC Serviço de Estimulação e Reabilitação da Criança (Gravatá), ODIP - Obra de Defesa da Infância Pobre (Gravatá), GAMR (Gravatá), Circulo de Trabalhadores Cristãos (Gravatá), Lar Santa Elisabeth (Triunfo), PROAC (Salgueiro), Centro Educacional Saber Viver (Recife), CEPOMA (Recife), Turma do Flau (Recife), Comunidade de Crianças e adolescentes de Rua (Caruaru), Creche Sol Poente (Caruaru), Centro de Formação de Menores (Limoeiro), CEMAN (Petrolina), Associação de Protetores do Meio Ambiente (Caruaru), Centro de Cidadania UMBÚ-GANZÁ (Recife), Centro de Educação Popular Assunção (Caruaru), entre outros.

ii O Programa de Estímulo à Criatividade na Educação Básica.

Disponível em< http://criatividade.mec.gov.br/a-iniciativa>. Acesso em: 10 set. 2015.

iii O Programa de Estímulo à Criatividade na Educação Básica.

Disponível em <http://criatividade.mec.gov.br/a-iniciativa>. Acesso em: 10 set. 2015.

iv 1989, pp.109-110.

v Algunas notas sobre los niños como sujeto social; documento del MANTHOC, não publicado.

vi Tomamos aqui a andarilhagem em sua concepção antropológica a partir de Carlos Rodrigues Brandão, para o qual "Somos humanos porque aprendemos a andar. Somos humanos porque aprendemos a pendular entre "estar aqui" e um contínuo "partir". Entre os que andam, viajam e vagam, há os que se deslocam porque querem (...) os que se deslocam porque precisam (os migrantes da fome, os exilados..." (BRANDÃO, Carlos Rodrigues. Andarilhagem In: STRECK, Danilo, R. RENDIN, Euclides, ZITIKOSKI, Jaime José, 2008 p. 40.

vii Die vom Kind auf der Straße erworbenen Kenntnisse und Erfahrungen sollen inm erhalten bleiben (a) Das Kind soll menschliches Überleben auf der Straße erlernen; (b) Der Erwachsene soll hierbei die Rolle des Begleiters und "Animators" übernehmen; (c) Der Erwachsene soll versuchen, aus dem Verständnis einer Arbeit mit dem Kind zu dem Verständnis eines Lebens mit dem Kind zu gelangen; (d) Der Erwachsene soll sich bereitfinden, von und mit dem Kindern zu lernen; (e) Das Kind muß an dem Aufbau eines ,neuen Lebens" voll beteiligt sein“. (DÜCKER 1996, p.195).

viii viele lateinamerikanische straßenpädagogen haben über educación popular zu einem neuen bewußtsein gefunden und die zum grundprinzip einer „erziehung auf der straße“, einer vom lebensfeld des kindes ausgehenden pädagogik erhoben: für die auf der straße lebenden kinder soll die straße „lernstoff“ bleiben und die „problematik“ eines menschlichen lebens auf der straße ständig thematisiert werden. ihre „lebenssituation“ soll innen „bewußt“ und nicht ausgeklammert werden, und schließlich zum inhalt allen lernens werden. sie sollen reflektieren und selbst neue lösungen formulieren lernen, wobei die 
straßenpädagogen die rolle der „provozierenden“ oder „animierenden“ einnehmen“ (Dücker 1996, p.47; ver também Liebel, 1994, p. 94-99.

x Gostaríamos de registrar que já desenvolvemos duas pesquisas neste projeto socioeducativo - "A educação pelo trabalho: uma aventura pedagógica na Comunidade de Menores de rua/Caruaru/PE" (1992 a 1995 - Mestrado em Educação Popular-UFPB) e "Produção de saberes e competências pelo Trabalho: a experiência de vida de crianças e adolescentes em situação de pobreza e o trabalho sócio-educativo dentro de Projetos Comunitários em Pernambuco/Brasil - Wissensproduktion und Kompetenzerwerb durch Arbeit: Lebenserfahrung von Kindern und Jugendlichen in Armut und erzieherische Maßnahmen in Bildungsprojekten in Pernambuco/Brasilien (1996 a 2000 - Doutorado em Pedagogia Social na Johann Wolfgang Goethe Universitat - Frankfurt) 